\title{
Implementasi Metode Modelling The Way dengan Permainan Mathchess untuk Meningkatkan Keterampilan Perkalian
}

\author{
*Dhika Mila Riananda1, Ervina Eka Subekti ${ }^{2}$, Moh Aniq KHB ${ }^{3}$
}

${ }^{123}$ Pendidikan Guru Sekolah Dasar, Universitas PGRI Semarang, Indonesia

\section{A R T I C L E I N F O \\ Article history: \\ Received 15 August 2019 \\ Received in revised form 20 September 2019 \\ Accepted 10 October 2019 \\ Available online 27 \\ November 2019}

Kata Kunci:

Modelling The Way,

Mathchess, Perkalian.

Keywords:

The Way Modeling Method,

Mathchess, Multiplication

Skills.

\begin{abstract}
A B S T R A K
Penguasaan kemampuan matematika yang masih rendah pada materi perkalian yang disebabkan oleh anak yang belum paham akan konsep perkalian. Sehinga penelitian ini tujuan yang hendak dicapai dalam penelitian ini adalah untuk mengetahui implementasi metode modelling the way dengan permainan mathchess dapat meningkatkan keterampilan perkalian siswa kelas II SD. Jenis penelitian ini adalah penelitian kuantitatif dalam bentuk Pre-Experiment Desaign dengan desain One Group Pretest-Posttest. Populasi dalam penelitian ini seluruh siswa kelas II SD. Sampel yang diambil adalah 22 siswa kelas II dengan teknik Probability Sampling berbentuk sampling jenuh. Data dalam penelitian ini diperoleh melalui tes, dokumentasi, dan observasi. Hasil penelitian menunjukkan bahwa nilai uji normalitas akhir atau posttest $(93,18)$ lebih besar dari hasil uji normalitas awal atau pretest $(64,77)$ serta berdasarkan hasil uji-t satu pihak diketahui thitung lebih dari tabel $(10,437>1,721)$. Dari hasil tersebut dapat disimpulkan bahwa $\mathrm{H}_{0}$ ditolak. Dengan kata lain terdapat pengaruh positif pada implementasi metode modelling the way dengan permainan mathchess dapat
\end{abstract} meningkatkan keterampilan perkalian siswa kelas II SD.

\begin{abstract}
A B S T R A C T
Mastery of mathematics ability that were still low on the multiplication material caused by children who did not understand the concept of multiplication. The aim of this research was to find out the implementation of the method of modeling the way with mathchess game can improve the multiplication skills of students in class II Tambakrejo 03 Semarang. This type of research is quantitative research in the form of Pre-Experiment Desaign with One Group Pretest-Posttest design. The population in this study were all grade II students of SD. Samples taken were 22 students of Class II with the Probability Sampling technique in the form of saturated sampling. Data in this study were obtained through tests, documentation, and observation. The results showed that the value of the final normality test or posttest (93.18) was greater than the results of the initial normality test or pretest (64.77) and based on the results of the one-party t-test it was known that tcount was more than ttable $(10.437>1,721)$. From these results it can be concluded that $\mathrm{HO}$ is rejected. In other words there is a positive influence on the implementation of the way modeling method with mathchess game can improve the multiplication skills of students in class II. Based on the results of this study, the suggestion that can be delivered is that the method of modeling the way with the Mathchess game can be used as an alternative teacher in teaching mathematics learning in class.
\end{abstract}

\section{Pendahuluan}

Pendidikan merupakan perihal yang sangat penting bagi setiap individu didunia yang menjadi patokan dan harapan guna meningkatkan kualitas hidup individu dan masyarakat. Pendidikan berperan aktif dalam menjadikan generasi penerus bangsa yang dapat merubah bangsa menjadi lebih baik dari sebelumnya, (Binov handitya, 2019). Menurut Undang-Undang Republik Indonesia No. 20 Tahun 2003 sesuai dengan fungsi dan tujuan dari pendidikan nasional tentang Sistem Pendidikan Nasional adalah :"Pendidikan Nasional berfungsi mengembangkan kemampuan dan membentuk watak serta peradaban

Copyright (c) Universitas Pendidikan Ganesha. All rights reserved. 
bangsa dan bertujuan untuk berkembangnya potensi peserta didik agar menjadi manusia yang beriman, dan bertaqwa kepada Tuhan Yang Maha Esa, berakhlaq mulia, sehat, berilmu, cakap, kreatif, mandiri dan menjadi warga Negara yang demokratis serta bertanggung jawab". Dalam dunia pendidikan tentunya mengenal banyak sekali berbagai macam pendidikan seperti pendidikan agama, pendidikan kewarganegaraan, bahasa, matematika, ilmu pengetahuan alam, ilmu pengetahuan social, seni dan budaya, pendidikan jasmani dan olahraga. Matematika merupakan sesuatu yang tidak asing di telinga bagi setiap kalangan individu karena kegunaan dan juga manfaatnya untuk setiap aktivitas kehidupan masyarakat. Matematika telah menjadi mata pelajaran yang sifatnya wajib untuk dipelajari bagi setiap kaum. Maka dari itu pelajaran matematika harus di terapkan mulai sejak jenjang pendidikan dasar. Teori pendidikan merupakan landasan dan pijakan awal dalam pengembangan praktik pendidikan, misalnya pengembangan kurikulum, manajemen sekolah dan proses belajarmengajar. Kurikulum dan pembelajaran memiliki keterkaitan dengan teori pendidikan atau dalam penyusunan suatu kurikulum dan rencana pembelajaran ini mengacu pada teori pendidikan (Sholichah, 2018).

Guru adalah salah satu unsur yang sangat penting dalam mencetak output pendidikan (peserta didik) yang berkualitas demi mewujudkan tujuan pendidikan nasional. Dalam Undang-undang Republik Indonesia No.14 Tahun 2005 tentang Guru dan Dosen, pada pasal 1 (Basri, 2017) menyatakn bahwa: "Guru adalah pendidik profesional dengan tugas utama mendidik, mengajar, membimbing, melatih, menilai dan mengevaluasi peserta didik pada pendidikan anak usia dini, jalur pendidikan formal, pendidikan dasar dan menengah". Dari Undang-undang di atas, maka jelaslah bahwa keprofesian guru dalam proses pembelajaran lebih ditekankan, disamping berkompeten bidang paedagogik, kepribadian, dan sosial. Karena keprofesionalan guru dalam proses pembelajaran mampu menciptakan suasana kelas kondusif, inovatif, kreatif, dan menyenangkan. Sehingga peserta didik termotivasi untuk belajar produktif, aktif dalam melaksanakan kegiatan pembelajaran dan dapat mengembangkan potensi diri peserta didik dalam memahami materi pelajaran.

(Hadi, 2017) Pendidikan matematika di tanah air saat ini sedang mengalami perubahan paradigma. Terdapat kesadaran yang kuat, terutama di kalangan pengambil kebijakan, untuk memperbarui pendidikan matematika. Tujuannya adalah agar pembelajaran matematika lebih bermakna bagi siswa dan dapat memberikan bekal kompetensi yang memadai baik untuk studi lanjut maupun untuk memasuki dunia kerja. Sedangkan Heruman (2007:4) menyatakan pembelajaran matematika di tingkat SD, diharapkan terjadi reinvention (penemuan kembali). Penemuan kembali adalah menemukan suatu cara penyelesaian secara informal dalam pembelajaran di kelas, (Zubaidah et al., 2015). Walaupun penemuan tersebut sederhana dan bukan hal baru bagi orang yang telah mengetahui sebelumya, tetapi bagi siswa SD penemuan tersebut merupakan sesuatu hal yang baru. Dalam kehidupan sehari-hari, matematika berperan sangat besar, oleh sebab itu siswa dituntut harus mampu menguasai pelajaran matematika. Dalam dunia matematika banyak sekali materinya, salah satu materi dalam matematika adalah perkalian. Perkalian merupakan materi yang sangat penting dalam pembelajaran matematika, sebab materi ini banyak terkait dengan materi yang lain dalam matematika. Namun dalam penyampaian materi perkalian terdapat kesulitam dalam metode pembelajaran maupun dalam pengadaan media pembelajaran. Hal ini sesaui dengan hasil observasi yang dilakukan.

Berdasarkan hasil observasi yang dilakukan di SD Tambakrejo 03 Semarang ditemukan permasalahan yang mana siswa kelas tinggi masih banyak yang belum menguasai materi tentang perkalian dan mereka belum hafal perkalian dari 1 sampai 10. Sedangkan (Riris Nur Kholidah Rambe, 2018)menyatakan bahwa dunia pendidikan kita ditandai oleh disparitas antara pencapaian academic standard dan performance standard. Faktanya, banyak peserta didik mampu menyajikan tingkat hafalan yang baik terhadap materi ajar yang diterimanya, namun pada kenyataannya mereka tidak memahaminya (Khasanah, 2011). Peserta didik memiliki kesulitan untuk memahami konsep akademik sebagaimana mereka bisa diajarkan yaitu dengan menggunakan sesuatu yang abstrak dan metode ceramah. Pendidikan tidak akan luput dari istilah pembelajaran dan pengajaran. Pembelajaran merupakan terjemahan dari learning dan pengajaran terjemahan dari teaching. Pembelajaran berdasarkan makna leksikal berarti proses, cara, perbuatan mempelajari. Perbedaan esensiil istilah ini dengan pengajaran adalah pada tindak ajar. Pada pengajaran guru mengajar, peserta didik belajar, sementara pada pembelajaran guru mengajar diartikan sebagai upaya guru mengorganisir lingkungan terjadinya pembelajaran. Guru mengajar dalam perspektif pembelajaran adalah guru menyediakan fasilitas belajar bagi peserta didiknya untuk mempelajarinya (Riris Nur Kholidah Rambe, 2018). Jadi, subjek pembelajaran adalah peserta didik. Pembelajaran berpusat pada peserta didik. Pembelajaran adalah dialog interaktif. Pembelajaran merupakan proses organik dan konstruktif, bukan mekanis seperti halnya pengajaran.

Pembelajaran yang baik adalah pembelajaran yang aktif dan menyenangkan bagi peserta didik. Yang mana dalam kaitannya pembelajaran membutuhkan sebuah motivasi belajar untuk menggugah semangat para peserta didik untu belajar. Belajar adalah perubahan tingkah laku secara relatif permanen 
dan secara potensial terjadi sebagai hasil dari praktik penguatan (motivasi) yang dilandasi tujuan tertentu (Ruslan et al., 2016). Korelasi ini menguatkan urgensitas motivasi belajar. Hakikat motivasi belajar adalah dorongan internal dan eksternal pada peserta didik yang sedang belajar untuk mengadakan perubahan perilaku. Motivasi belajar adalah proses yang memberi semangat belajar, arah, dan kegigihan perilaku. Artinya, perilaku yang termotivasi adalah perlikau yang penuh energi, terarah dan bertahan lama. A. Suprijono (2011 : 162). Modelling The Way dengan permainan Mathchess.

Metode modelling the way metode yang dapat memberikan kesempatan kepada siswa untuk mempraktekkan keterampilan spesifik yang dipelajari di kelas melalui demonstrasi, (Ardi Rakasiwi, 2018). Metode modeling the way menempatkan siswa sebagai bagian suatu sistem yang bekerja sama dalam mencapai suatu hasil yang optimal dalam belajar (Sihotang \& Sari, 2018). Model ini mempunyai keunikan dibandingkan dengan model lain yaitu keistimewaannya dibandingkan dengan metode demonstrasi adalah metode modelling the way membuat siswa lebih aktif dalam belajar, siswa menjadi lebih berani untuk mempraktekkan sesuatu dan tidak takut, siswa aktif memberikan tanggapan, menambahkan kesadaran akan tanggungjawab terhadap tugas yang diberikan dan siswa mengalami langsung keterampilan yang dipraktekkan, (Ardi Rakasiwi, 2018). Adapun Langkah-langkan model ini yaitu: 1) Setelah pembelajaran satu topik tertentu, identifikasi beberapa masalah dan siswa di tuntut untuk mengunakan keterampilan yang dibahas. 2) Membagi kelas ke dalam beberapa kelompok kecil menurut jumlah siswa yang diperlukan untuk mendemonstrasi satu skenario (minimal 2 atau 3 orang) 3) Memberi waktu 10-15 menit untuk menciptakan skenario. 4) Memberi waktu 5-7 menit untuk pelatihan. 5) Secara bergiliran tiap kelompok mendemonstrasikan skenario masing-masing. dan 6) Memberi kesempatan untuk memberikan feedback pada setiap demonstrasi yang dilakukan. (Ardi Rakasiwi, 2018)

Hasil penelitian tersebut selaras dengan hasil penelitian sebelumnya yang dilakukan Titik Nurwulan yang berjudul Implementasi metode modelling the way dalam meningkatkan kualitas pembelajaran matematika siswa kelas IV MI Ma'aruf Surodikraman Ponorogo tahun pelajaran 2011/2012.Dari hasil analisis siswa data yang di dapatkan bahwa (a) Aktivitas belajar matematika siswa selama pembelajaran secara keseluruhan efektif. Hal ini dapat dilihat dari aspek pengamatan yang dilakukan siswa tiap siklus aktivitas siswa yang termasuk kategori efektif lebih banyak daripada yang tidak efektif. (b) Hasil belajar siswa mengalami peningkatan dari siklus I sampai siklus II yaitu siklus I (75\%), siklus II (92\%). (c) Pengelolaan pembelajaran yang dilakukan guru berjalan dengan baik. (d) Siswa sangat tertarik terhadap pembelajaran yang telah diterapkan. Kesimpulan dari penelitian ini adalah pembelajaran aktif Modelling the way membuat siswa lebih memahami materi, lebih aktif belajar dan lebih berani mengungkapkan pendapat sehingga dapat meningkatkan kualitas pembelajaran matematika siswa keklas IV MI Ma'aruf Surodikraman Ponorogo.

Hasil penelitian terdahulu yakni (Masykuri, 2013)yang berjudul Upaya Meningkatkan Keterampilan Berbicara Melalui Model Pembelajaran Modeling The way Pada Mata Pelajaran Bahasa Indonesia Siswa Kelas V MIM Bekangan Boyolali Tahun Ajaran 2012/2013. Penelitian ini bertujuan untuk meningkatkan ketrampilan berbicara bahasa indonesia melalui penerapan model pembelajaran Modeling The Way. Subyek dari penelitian ini adalah guru dan siswa kelas V MIM Bekangan yang berjumlah 23 siswa yang terdiri dari 8 siswa laki - laki, dan 15 siswa perempuan, tindakan, pengamatan dan refleksi. Teknik pengumpulan data dilakukan melalui wawancaraobservasi, dokumentasi, tes. Sedangkan teknik analisis data menggunakan reduksi data, penyajian data, kesimpulan. Berdasarkan hasil penelitian menunjukkan adanya peningkatan ketrampilan berbicara Bahasa Indonesia pada materi Drama. Indikator pencapaian peningkatan yaitu sekurang-kurangnya $70 \%$ siswa memperoleh nilai $\geq \mathrm{KKm}$ yaitu $\geq 70$, sekurangkurangnya 70\% dari 23 siswa yaitu sekitar 16 anak mengalami peningkatan ketrampilan berbicara dalam Bahasa Indonesia. Peningkatan ketrampilan berbicara dalam Bahasa Indonesia dengan hasil belajar tes unjuk kerja siswa yang diperoleh data pada prasiklus sebanyak 9 siswa atau sebesar 39,13\% mengalami ketuntasan, siklus I sebanyak 16 siswa atau sebesar $69,56 \%$ mengalami ketuntasan, pada siklus II prosentase ketuntasan yang diperoleh sebanyak 20 siswa atau sebesar $86,97 \%$. Kesimpulan penelitian ini adalah bahwa penerapan Modeling The Way dapat meningkatkan ketrampilan berbicara pada mata pelajaran Bahasa Indonesia Siswa kelas V MIM Bekangan tahun ajaran 2012/2013.

Dari latar belakang di atas penulis akan melakukan penelitian dengan judul "Implementasi metode Modelling The Way dengan permainan Mathchess untuk meningkatkan keterampilan perkalian siswa kelas II Sd Tambakrejo 03 Semarang". Tujuan yang hendak dicapai dalam penelitian ini adalah untuk mengetahui implementasi metode modelling the way dengan permainan mathchess dapat meningkatkan keterampilan perkalian siswa kelas II SD. 


\section{Metode}

Penelitian ini menggunakan Pre-Experimental Design tipe One-Group Pretest-posttest Design. Dalam bentuk desain ini yang menggunakan satu kelas kontrol yang di dalamnya terdapat pemberian perlakuan kepada subyek. Siswa nantinya akan diberikan perlakuan dalam proses pembelajaran untuk meningkatkan hasil belajar dan dilihat dari nilai ketuntasan siswa. Pada desain penelitian ini terdapat pretest sebelum diberikan perlakuan. Dengan demikian hasil perlakuan dapat diketahui lebih akurat, karena dapat membandingkan dengan keadaan sebelum dan sesudah diberi perlakuan. Dalam hal ini perlakuan digunakan untuk mencari perbandingan tingkat keterampilan perkalian siswa kelas II SD Tambakrejo 03 Semarang sebelum dan sesudah menggunakan metode Modelling the Way dengan permainan Mathchess.

Berdasarkan desain penelitian tersebut, terdapat satu kelas yang akan diberikan soal pada awal pembelajaran berupa Pretest untuk mengukur hasil belajar siswa sebelum pemberian perlakuan. Setelah diberikan Pretest selanjutnya siswa akan diberi perlakuan yaitu pembelajaran dengan menggunakan metode Modelling the Way dengan permainan Mathchess. Pada akhir pembelajaran, siswa akan diberi soal Posttest dan langkah selanjutnya membandingkan hasil belajar dari Pretest dan Posttest dalam pembelajaran tersebut. Prosedur penelitian digambarkan pada gambar 1 berikut.

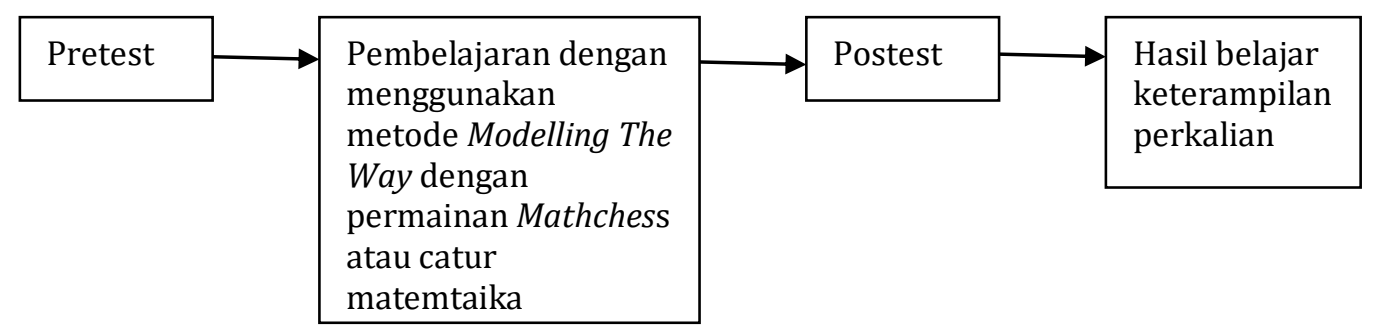

Gambar 1.

Bagan Prosedur Penelitian

Sampel penelitian ini diperoleh dari SD Tambakrejo 03 Semarang. Untuk menentukan instrumen penelitian maka perlu dilakukan uji coba instrumen utuk pretest dan posttest. Uji coba instrumen dalam penelitian ini berjumlah 30 butir soal.

Setelah dilakukan uji coba instrumen, kemudian hasil uji coba instumen tersebut diuji dengan uji validitas, reliabilitas, tingkat kesukaran, dan daya pembeda. Dari hasil uji tersebut, didapatkan 22 soal yang valid. Untuk memudahkan perhitungan dalam penskoran maka jumlah soal yang digunakan yaitu 20 butir soal. Berdasarkan bagan di atas dapat diuraikan dalam penelitian ini, peneliti terlebih dahulu membuat soal berdasarkan kisi-kisi. Peneliti selanjutnya melakukan uji coba soal pada kelas yang dipilih. Uji coba soal ini bertujuan untuk mengetahui validitas butir soal, tingkat kesukaran dan daya beda melalui analisis data. Peneliti memulai dengan melakukan pretest. Pretest ini bertujuan untuk menganalisa data awal. Setelah diberi perlakuan, peneliti menggunakan soal posttest. Pemberian soal posttest ini bertujuan untuk mengetahui hasil posttest yang nantinya akan digunakan untuk menyuksun hasil penelitian.

\section{Hasil dan Pembahasan}

Pada Penelitian ini di laksanakan di SD Tambakrejo 03 Semarang. Dalam penelitian ini ada 2 variabel yaitu : (1) Variabel bebas (Y) Implementasi Metode Modelling The Way dengan Permainan Mathchess dan (2) Variabel terikat (X) Keterampilan Perkalian Siswa Kelas II SD Tambakrejo 03 Semarang. Penelitian ini merupakan penelitian kuantitatif dengan jenis One group pretest-posttestDesaign. Data penelitian ini terdiri atas data pretest dan posttest pada tema 2 Bermain Di Lingkunganku subtema 1 Bermain di Lingkungan Rumah khusunya mata pelajaran matematika. Nilai hasil pretest sebagai pengukur kemampuan awal siswa dan nilai hasil posttest diambil dari hasil pengerjaan soal oleh siswa setelah dilakukan pembelajaran dengan metode modelling the way dengan permainan mathchess.

Berdasarkan panjang kelas interval tersebut dapat digunakan utuk menentukan daftar distribusi frekuensi seperti pada tabel 1 sebagai berikut:

Tabel 1. Distribusi Frekuensi Nilai Pretest

\begin{tabular}{lll}
\hline Interval & Frekuensi & Persentase \\
\hline $35-47$ & 2 & $9 \%$
\end{tabular}




\begin{tabular}{lll}
$48-60$ & 8 & $36 \%$ \\
$61-73$ & 5 & $23 \%$ \\
$74-86$ & 7 & $32 \%$ \\
$87-99$ & - & - \\
Jumlah & 22 & $100 \%$ \\
\hline
\end{tabular}

Dapat diketahui bahwa frekuensi hasil pretest yang memperoleh nilai 35-47 yaitu sebanyak 2 siswa atau 9\%, nilai 48-60 yaitu sebanyak 8 siswa atau 36\%, nilai $61-73$ yaitu sebanyak 5 siswa atau $23 \%$, sedangkan nilai 74-86 yaitu sebanyak 7 siswa atau 32\%, dan yang mendapatkan nilai 88-99 yaitu sebanyak 0 siswa atau $0 \%$. Selanjutnya, distribusi frekuensi nilai pretest dapat disajikan dalam bentuk bagan gambar 2 berikut:

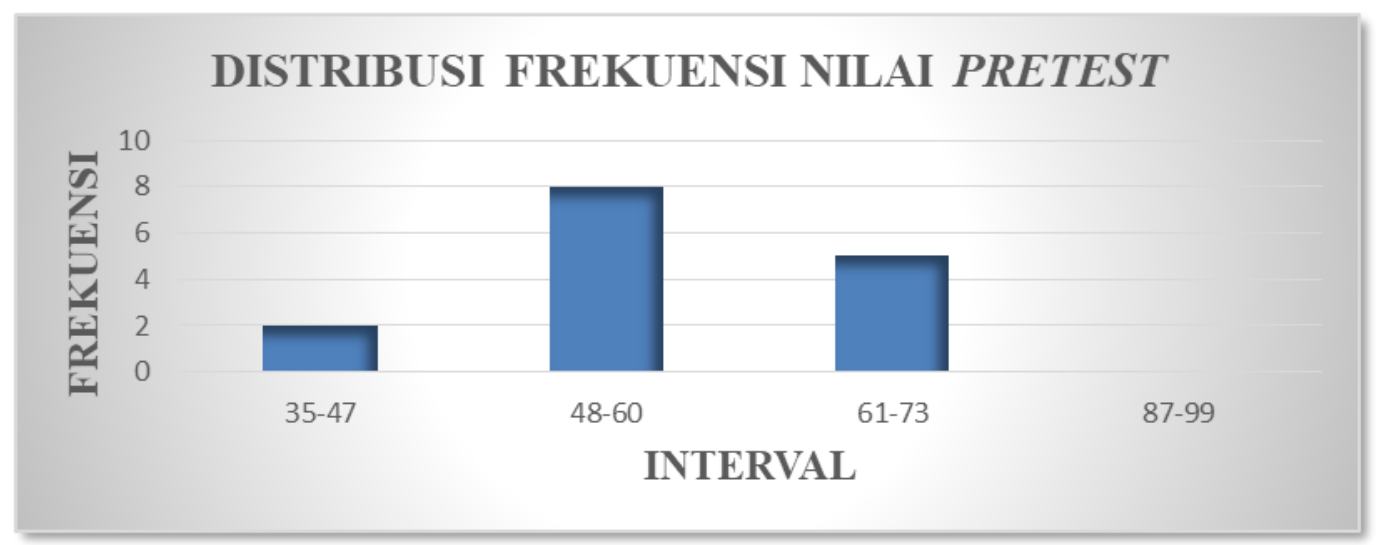

Gambar 2.

Diagram Histogram Nilai Pretest

Berdasarkan hasil perhitungan normalitas awal diperoleh data seperti pada tabel 3:

Tabel 3. Normalitas Awal

\begin{tabular}{llllll}
\hline Jenis & N & Lo & Ltabel & Keterangan & Kesimpulan \\
\hline Pretest & 22 & 0,0913 & 0,19 & $L_{0}<L_{\text {tabel }}$ & Berdistribusi normal \\
\hline
\end{tabular}

Berdasarkan data pretest yang dihitung menggunakan uji Liliefors diperoleh data $\mathrm{L}_{\text {tabel }}=0,19$ dan $\mathrm{L}_{0}$ $=0,0913$. Karena $\mathrm{L}_{0}<\mathrm{Ltabel}$ maka $\mathrm{H} 0$ diterima. Artinya, data nilai awal tersebut berasal dari populasi yang berdistribusi normal.Setelah ditentukan nilai panjang kelas,maka dapat dijadkan sebagai pedoman untuk menentukan daftar distribusi frekuensi. Berikut adalah daftar frekuensi nilai posttest dapat dilihat pada tabel berikut ini:

Tabel 4. Distribusi Frekuensi Nilai Posttest

\begin{tabular}{lll}
\hline Interval & Frekuensi & Persentase \\
\hline $70-75$ & 1 & $4 \%$ \\
$76-82$ & 1 & $4 \%$ \\
$83-88$ & 1 & $4 \%$ \\
$89-94$ & 4 & $19 \%$ \\
$95-100$ & 15 & $69 \%$ \\
Jumlah & 22 & $100 \%$ \\
\hline
\end{tabular}

Dapat diketahui bahwa frekuensi hasil posttest siswa yang memperoleh nilai 70-75 sebanyak 1 siswa dengan persentase $4 \%$, nilai 76-82 sebanyak 1 dengan persentase $4 \%$, nilai 83-88 sebanyak 1 siswa dengan persentase $4 \%$, nilai 89-94 sebanyak 4 siswa dengan persentase $19 \%$, dan nilai 95-100 
sebanyak 15 siswa dengan persentase $69 \%$. Selanjutnya data frekuensi nilai posttest siswa dapat disajikan dalam bentuk gambar 3 berikut:

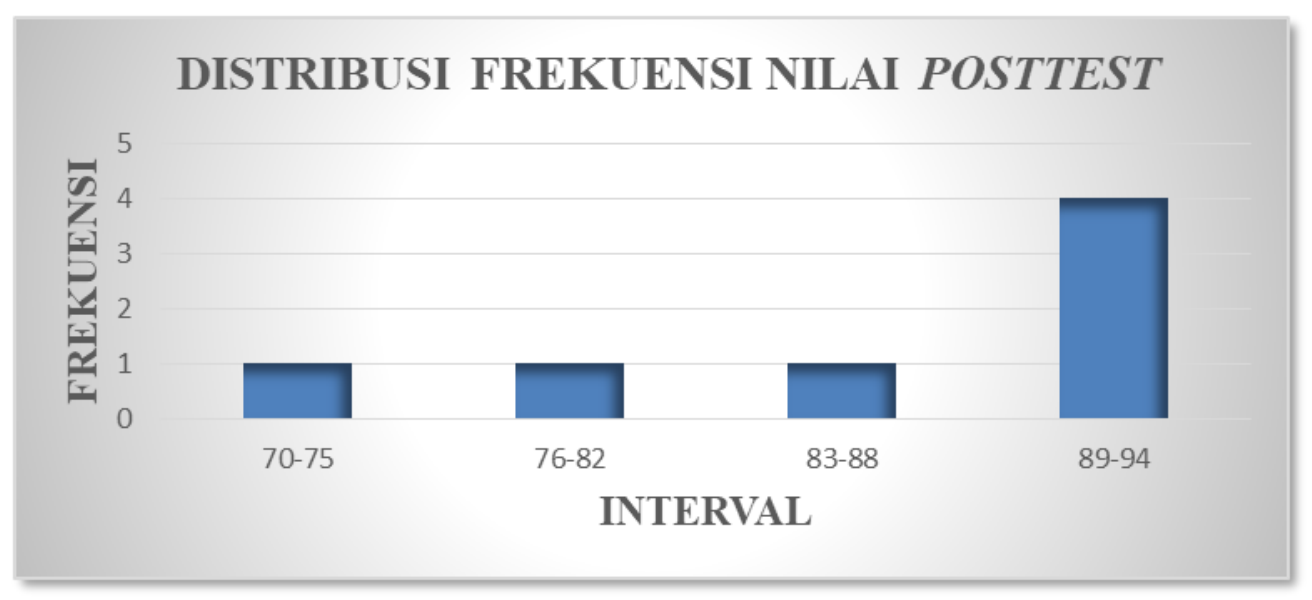

Gambar 3.

Diagram Histogram Nilai Posttest

Data yang dgunakan dalam uji normalitas akhir adalah data hasil posttest.

Tabel 5. Normalitas Akhir

\begin{tabular}{llllll}
\hline Jenis & $\mathbf{N}$ & $\mathbf{L}_{\mathbf{0}}$ & $\mathbf{L}_{\text {tabel }}$ & Keterangan & Kesimpulan \\
\hline Posttest & 22 & 0,1762 & 0,19 & $\mathrm{~L}_{0}<\mathrm{L}_{\text {tabel }}$ & Berdistribusi normal \\
\hline
\end{tabular}

Berdasarkan data hasil posttest diperoleh data yaitu $\mathrm{L}_{0}=0,1762$. Dengan banyaknya data $=22$, untuk taraf signifikansi 5\% maka dari tabel Liliefors diperoleh Ltabel $=0,19$. Maka L $<$ Ltabel artinya, data nilai siswa tersebut berasal dari populasi yang berdistribusi normal.

Hipotesis hasil belajar yang disajikan adalah sebagai berikut:

$\mathrm{H}_{0}: \mu 1=\mu 2$ (hasil posttest siswa kelas II sama dengan hasil pretest siswa)

$\mathrm{H}_{\mathrm{a}}: \mu 1>\mu 2$ (hasil posttest siswa kelas II lebih baik dibanding hasil pretest siswa)

Berdasarkan hasil perhitungan uji-t satu pihak antara nilai pretest dan nilai posttest maka diperoleh data pada tabel 6 berikut:

Tabel 6.Uji-t Satu Pihak

\begin{tabular}{llll}
\hline Thitung & $\mathrm{T}_{\text {tabel }}$ & Keterangan & Kesimpulan \\
\hline 10,473 & 1,721 & $\mathrm{~T}_{\text {hitung }}>\mathrm{T}_{\text {tabel }}$ & $\mathrm{H}_{0}$ ditolak \\
\hline
\end{tabular}

Berdasarkan perhitungan di atas diperoleh thitung $=10,473$. Hal tersebut kemudian dikonsultasikan dengan tabel dari tabel distribusi t dengan $\mathrm{db}=\mathrm{N}-1=22-1=21$, dan taraf signifikan 0,05 sebesar 1,721. Karena thitung $>$ table yaitu 10,473 $>1,721$, maka $\mathrm{H}_{0}$ ditolak dan $\mathrm{H}_{a}$ diterima. Jadi terdapat perbedaan signifikan nilai hasil pretest dan posttest. Sebelum perhitungan uji-t, data akhir setelah diberikan perlakuan pada siswa dapat meningkatkan hasil belajar anak. Hal ini dibuktikan dengan nilai data awal dan nilai data akhir siswa meningkat dengan rata-rata pretest yaitu 64,77 sedangkan rata-rata posttest yaitu 93,18. Dari data tersebut dapat disimpulkan bahwa data posttest meningkat signifikan dibandingan dengan data pretest.

Berdasarkan penelitian yang dilakukan peneliti dengan judul penelitian yakni Implementasi Metode Modelling The Way dengan Permainan Mathchess Untuk Meningkatkan Keterampilan Perkalian Siswa Kelas II SD Tambakrejo 03 Semarang. Peneliti menyimpulkan bahwa penelitian ini dilakukan karena didasari oleh beberapa masalah yang ada pada kelas tersebut. Masalah tersebut di lihat oleh peneliti pada saat kegiatan observasi. Masalah yang muncul saat dilakukan observasi yaitu pada saat pembelajaran matematika khususnya pada materi perkalian di kelas II SD Tambakrejo 03 Semarang. Bahwa dalam observasi yang dilakukan pembelajaran matematika khususnya materi perkalian belum menggunakan metode, model dan media pembelajaran yang sesuai dengan karakteristik siswa untuk mendukung proses belajar mengajar. Masalah yang lain yakni banyak siswa di kelas tinggi yang masih 
rendah kemampuannya dalam menghafal perkalian dan mengucapkannya dengan cepat dan tepat. Dalam kegiatan observasi yang peneliti lakukan di kelas tinggi, peneliti menguji tingkat kemampuan perkalian siswa khususnya di kelas V SD Tambakrejo 03 Semarang. Masih terdapat beberapa siswa yang kurang dalam hafalan perkalian dan masih membutuhkan alat bantu seperti jari untuk membantu dalam menghitung perkalian. Hal ini yang membuat peneliti ingin melakukan penelitian dengan judul Implementasi Metode Modelling The Way dengan Permainan Mathchess Untuk Meningkatkan Keterampilan Perkalian Siswa Kelas II SD Tambakrejo 03 Semarang. Guna untuk mengantisipasi terjadinya masalah tersebut. Pada penelitian ini terlihat bahwa pada siswa kelas II masih banyak siswa yang kurang dalam keterampilan perkalian yang ditunjukkan dengan salah satu hasil ulangan siswa yang mendapat nilai rendah. Untuk itu diperlukan sebuah solusi atau ide yang tepat untuk mengatasi beberapa masalah tersebut. Diperlukan metode, model dan media yang tepat yang sesuai dengan materi yang diajarkan kepada siswa. Peneliti memilih solusi yang tepat untuk mengatasi masalah tersebut yakni dengan menggunakan Metode Modelling The Way dengan permainan Mathchess untuk meningkatkan keetrampilan perkalian siswa kelas II SD Tambakrejo 03 Semarang.

Penelitian ini menggunakan tipe Pre-Eksperimental One-Group Pretest-Posttest Design yakni hanya menggunakan satu kelas yang digunakan sebagai subyek penelitian. Sebelum proses penelitian, peneliti menentukan instrumen penelitian yang tepat maka dari itu perlu dilakukan uji coba instrumen guna menentukan soal yang akan digunakan untuk penelitian yakni soal pretest dan posttest. Uji coba instrumen dalam proses penelitian ini berjumlah 30 butir soal pilijan ganda dengan 4 pilihan yakni (a, b, c dan d). Kemudian setelah dilakukan uji coba instrumen hasil uji coba instrumen tersebut diuji dengan uji validitas dengan soal yang valid berjumlah 22 soal, reliabilitas, yang kemudian dihitung tingkat kesukaran hasil soal diantaranya soal dengan tingkat kesukaran yang mudah berjumlah 8 soal, tingkat kesukaran soal yang sedang berjumlah 21 soal dan tingkat kesukaran soal yang sukar berjumlah 1 soal. Kemudian hasil perhitungan menggunakan uji daya pembeda berdasarkan perhitungan diketahui terdapat 13 soal dengan kriteria baik sekali, 5 soal dengan kriteria baik, 5 soal dengan kriteria cukup, 1 soal dengan kriteria jelek dan 6 soal dengan kriteria sangat jelek. Dalam uji coba soal instrumen tersebut, hasil uji coba soal yang dapat digunakan dalam kegiatan penelitian yakni terdapat 22 soal valid. Sehingga soal yang dapat digunakan untuk proses kegiatan penelitian yakni untuk soal pretest dan posttest adalah 20 butir soal pilihan ganda yang sudah mewakili masing-masing indikator.

Pada saat kegiatan penelitian, peneliti membutuhkan waktu 3 kali pertemuan. Pada pertemuan pertama siswa diberikan soal pretest untuk mengetahui hasil sebelum diberikan tindakan. Setelah melaksanakan pretest atau tes sebelum diberi perlakukan, kemudian pertemuan kedua peneliti melakukan kegiatan pembelajaran secara langsung di dalam kelas sesuai dengan materi dan indikator dalam RPP yang akan diajarkan kepada siswa dengan menggunakan metode Modelling The Way dengan permainan Mathchess. Selanjutnya pertemuan ketiga siswa diberikan soal posttest sebagai test akhir untuk mengetahui hasil belajat keterampilan perkalian siswa setelah diberikan tindakan atau perlakukan. Dalam pembelajaran di kelas siswa diberi perlakuan menggunakan metode modelling the way dengan permainan mathchess sangat antusias dalam kegiatan pembelajaran.

Analisis data yang telah dilakukan oleh peneliti dalam penelitian ini terdiri dari data awal dan data akhir. Analisis data awal dapat dilihat dari pretest dari sebelum diberikan perlakuan dengan menggunakan metode modelling the way dengan permainan mathchess yang sudah di uji normalitasnya dengan menggunakan uji lilliefors. Pada tahap awal dimana siswa sebelum diberikan perlakuan dalam kegiatan pembelajaran siswa diberikan soal pretest untuk mengetahui tingkat kemampuan awal siswa sebelum nanti diberikan perlakuan dengan metode modelling the way dengan permainan mathchess. Setelah dilakukan pretest selanjutnya siswa akan di uji dengan uji normalitas awal. Hal tersebut dilakukan untuk mengetahui apakah sampel berdistribusi normal atau sampel berdistribusi tidak normal.

Pada saat pemberian soal pretest sebelum diberikan perlakuan nilai siswa masih terdapat nilai dibawah 50. Siswa yang bernama Silvia Azha Ramadhani mendapat nilai 35, yakni nilai terendah saat melakukan pretest. Sedangkan nilai pretest tertinggi adalah 85, ada 3 siswa yakni Dhia Aziza Okta Choirunnisa, Melinda Risma Nova Dewi A. dan Warah Nitisara Andini.

Pada saat pemberian soal posttest setelah diberikan perlakuan nilai siswa jauh lebih baik daripada nilai pretest siswa. Nilai tertinggi posttest adalah 100. Siswa yang mendapatkan nilai 100 yakni ada 11 siswa antara lain : Adam Arya Putra, Alvin Akmalul Huda, Dhia Aziza Okta Choirunnisa, Ikhsan Shareef Maulana, Iqbal Pamungkas, Lucky Ardian Syahputra, Nada Hilma Tsabita, Nayla Kusumadewi, Safa Nur Artania, Talita Latifa, Warah Nitisara Andini. Sedangkan siswa yang mendapat nilai terendah pada posttest adalah 70 diperoleh siswa yang bernama Marsya Ayu Fernanda.

Berdasarkan perhitungan pretest diperoleh bahwa kelas II SD Tambakrejo 03 Semarang berdistribusi normal karena nilai yang didapatkan dalam $\mathrm{L}_{0}<\mathrm{L}_{\text {tabel, }}$, bahwa $\mathrm{L}_{\text {tabel }}=0,190$ dengan taraf signifikan $5 \%$, sedangkan nilai yang didapat dalam $\mathrm{L}_{0}$ adalah 0,0915 , dengan diketahui bahwa nilai rata- 
rata sebesar 64,77 dari siswa yang berjumlah 22 siswa. Setelah siswa diberikan soal pretest siswa diberi perlakuan dengan menggunakan metode modelling the way dengan permainan mathchess. Pada tahap akhir dilakukan kembali uji normalitas akhir dengan menggunakan posttest. Berdasarkan perhitungan diperoleh $\mathrm{L}$ tabel $=0,190$ dengan taraf signifikan $5 \%$, nilai yang didapat dalam perhitungan uji normalitas data akhir atau posttest bahwa $\mathrm{L}_{0}$ yang diperoleh adalah 0,1762 . Karena $\mathrm{L}_{0}<\mathrm{L}_{\text {tabel }}$ maka dapat disimpulkan bahwa sampel yang diperoleh berdistribusi normal, dengan diketahui bahwa nilai rata-rata yang diperoleh dari siswa yang berjumlah 22 siswa adalah 93,18. Dalam hal ini menunjukkan bahwa terjadi peningkatan pada hasil belajar keetrampilan perkalian siswa di kelas II dengan implementasi metode modelling the way dengan permainan mathchess untuk meningkatkan keterampilan perkalian siswa kelas II SD Tambakrejo 03 Semarang.

Hasil penelitian dengan menggunakan metode modelling the way dengan permainan mathchess menunjukkan bahwa rata-rata nilai posttest sebesar 93,18 sedangkan rata-rata pretest sebesar 64,77 . Hal ini dapat menunjukkan secara jelas bahwa implementasi metode modelling the way dengan permainan mathchess berpengaruh terhadap hasil belajar keterampilan perkalian siswa kelas II pada tema 2 Bermain di Lingkunganku subtema 1 Bermain di Lingkungan Rumah pembelajaran 1.

Berdasarkan uji-t satu pihak yang telah dilaksanakan yaitu diperoleh nilai thitung $=10,437$ dan tabel $=$ 1,721 dengan $\mathrm{db}=\mathrm{N}-1=22-1=21$ dengan taraf signifikansi $5 \%$, maka thitung $>$ trabel maka $\mathrm{H}_{0}$ ditolak dan $\mathrm{H}_{a}$ diterima. Jadi terdapat perbedaan signifikan nilai hasil pretest dan posttest meningkat. Sehingga dapat dikatakan bahwa metode modelling the way dengan permainan mathchess berpengaruh untuk meningkatkan keterampilan perkalian siswa kelas II SD Tambakrejo 03 Semarang.

Pertama, implementasi metode modelling the way dengan permainan mathchess dapat meningkatkan ketrampilan perkalian siswa kelas II SD Tambakrejo 03 Semarang. Karena model ini lebih mengaktifkan siswa belajar dan memberikan kesampatan kepada siswa untuk mempratikkna pengetahunnya. Metode modelling the way metode yang dapat memberikan kesempatan kepada siswa untuk mempraktekkan keterampilan spesifik yang dipelajari di kelas melalui demonstrasi, (Ardi Rakasiwi, 2018). Metode modeling the way menempatkan siswa sebagai bagian suatu sistem yang bekerja sama dalam mencapai suatu hasil yang optimal dalam belajar (Sihotang \& Sari, 2018). Model ini mempunyai keunikan dibandingkan dengan model lain yaitu keistimewaannya dibandingkan dengan metode demonstrasi adalah metode modelling the way membuat siswa lebih aktif dalam belajar, siswa menjadi lebih berani untuk mempraktekkan sesuatu dan tidak takut, siswa aktif memberikan tanggapan, menambahkan kesadaran akan tanggungjawab terhadap tugas yang diberikan dan siswa mengalami langsung keterampilan yang dipraktekkan, (Ardi Rakasiwi, 2018).

Kedua, implementasi metode modelling the way dengan permainan mathchess dapat meningkatkan hasil belajar keterampilan perkalian siswa, semangat belajar siswa dan sikap antusias siswa. Belajar adalah proses memperoleh pengetahuan. Hal tersebut sejalan dengan pendapat Agus Suprijono (2017:3) Belajar adalah proses mendapatkan pengetahuan. Belajar sebagai konsep mendapatkan pengetahuan dalam praktiknya banyak dianut. Guru bertindak sebagai pengajar yang berusaha memberikan ilmu pengetahuan sebanyak-banyaknya dan peserta didik giat mengumpulkan atau menerimanya. Proses belajar mengajar ini banyaj didominasi aktivitas menghafal. Peserta didik sudah belajar jika mereka sudah hafal dengan hal-hal yang telah dipelajarinya. Tujuan belajar sebenarnya sangat banyak dan bervariasi. Tujuan belajar yang eksplisit diusahakan untuk dicapai dengan tindakan instruksional, lazim dinamakan instructional effects, yang biasa berbentuk pengetahuan dan keterampilan. Menurut A.Suprijono (2017:7) John Traves menggolongkan kegiatan belajar menjadi belajar gerakan, belajar pengetahuan, dan belajar pemecahan masalah. Ada pula yang menggolongkan kegiatan belajar menjadi belajar informasi, belajar konsep, belajar prinsip, belajar keterampilan dan belajar sikap. Secara ekletis, kategorisasi kegiatan belajar yang bermacam0macam tersebut dapat dirangkum menjadi tipe kegiatan belajar : 1)Keterampilan, 2) Pengetahuan, 3) Informasi, 4) Konsep, 5) Sikap, dan 6) Pemecahan masalah

Kegiatan belajar keterampilan berfokus pada pengalaman belajar melalui gerak yang dilakukan peserta didik. Kegiatan belajar ini merupakan paduan gerak, stimulus, dan respons yang tergabung dalam situasi belajar. Ketiga unsur ini menumbuhkan pola gerak yang terkoordinasi pada diri peserta didik. Kegiatan belajar keterampilan terjadi jika peserta didik menerima stimulus kemudian merespons dengan menggunakan gerak (John F. Travers, 2002). Kegiatan belajar keterampilan berfokus pada pengalaman belajar melalui gerak yang dilakukan peserta didik. Kegiatan belajar ini merupakan paduan gerak, stimulus, dan respons yang tergabung dalam situasi belajar. Ketiga unsur ini menumbuhkan pola gerak yang terkoordinasi pada diri peserta didik. Kegiatan belajar keterampilan terjadi jika peserta didik menerima stimulus kemudian merespons dengan menggunakan gerak.

Kegiatan belajar pengetahuan merupakan dasar bagi semua kegiatan belajar. Kegiatan belajar pengetahuan termasuk ranah kognitif. Ranah ini mencakup pemahaman terhadap suatu pengetahuan, perkembangan kemampuan dan keterampilan berpikir. Kegiatan belajar informasi adalah kegiatan 
peserta didik memahami simbol, seperti kata. Istilah, pengertian, dan peraturan. Kegiatan belajar informasi wujudnya berupa hafalan. Peserta didik mengenali, mengulang, dan mengingat fakta atau pengetahuan yang dipelajari. Belajar informasi ke dalam rangkaian bermakna bagi peserta didik dalam kehidupannya.

Kegiatan belajar konsep adalah belajar mengembangkan inferensi logika atau membuat generalisasi dari fakta ke konsep (Suprijanto, dalam (Wardani et al., 2016). Konsep merupakan kata kunci. Tidak semua kata disebut kata kunci, jika kata itu tidak memiliki sifat umum dan abstrak. Menurut Suprijanto (Permatasari, 2014) Konsep adalah ide atau pengertian umum yang disusun dengan kata, simbol, dan tanda. Konsep merupakan satu ide yang mengombinasikan beberapa unsur sumber-sumber berbeda ke dalam satu gagasan tunggal. Konsep dapat diartikan sebagai suatu jaringan hubungan dalam objek, kejadian, dan lain-lain yang mempunyai ciri-ciri tetap dan dapat diobservasi. Konsep atau kata kunci adalah variabel yang mempunyai variasi nilai. Konsep mengandung hal-hal yang umum dari sejumlah objek maupun peristiwa.

Kegiatan belajar sikap atau yang dikenal dengan kegiatan belajar efektif. Kegiatan belajar ini lebih tepat menggunakan istilah pendidikan daripada pembelajaran maupun pengajaran. Sikap diartikan sebagai pola tindakan peserta didik dalam merespons stimulus tertentu. Sikap merupakan kecendurungan atau predisposisi perasaan dan perbuatan yang konsisten pada diri seseorang. Sikap berhubungan dengan minat, nilai, penghargaan, pendapat dan prasangka. Dalam kegiatan belajar sikap, upaya guru adalah membantu peserta didik memiliki dan mengembangkan perubahan sikap.

Kegiatan belajar memecahkan masalah merupakan tipe kegiatan belajar dalam usaha mengembangkan kemampuan berpikir. Berpikir adalah aktivitas kognitif tingkat tinggi. Berpikir melibatkan asimilasi dan akomodasi berbagai pengetahuan dan struktur kognitif atau skema kognitif yang dimiliki peserta didik untuk memecahkan persoalan. Dalam kegiatan belajar pemecahan masalah peserta didik terlibat dalam berbagai tugas, penentuan tujuan yang ingin dicapai dan kegiatan untuk melaksanakan tugas.

Agus Suprijono (2017:73) Pembelajaran kooperatif (cooperative learning) adalah konsep yang lebih luas meliputi semua jenis kerja kelompok termasuk bentuk-bentuk yang lebih dipimpin oleh guru atau diarahkan oleh guru. Secara umum pembelajaran kooperatif dianggap lebih diarahkan oleh guru, dimana guru menetapkan tugas dan pertanyaan-pertanyaan serta menyediakan bahan-bahan dan informasi yang dirancang untuk membantu peserta didik menyelesaikan masalah yang dimaksud. Guru biasanya menetapkan bentuk ujian tertentu pada akhir tugas.

Eka L. Karunia (2017:43) Cooperative Learning adalah suatu model pembelajaran di mana siswa belajar dan bekerja secara kolaboratif dalam suatu kelompok heterogen. Pembelajaran ini bertujuan untuk mengembangkan prestasi akademis, keterampilan sosial, dan menanamkan toleransi dan penerimaan terhadap keanekaragaman individu. Tiga karakteristik utama dalam model pembelajaran ini adalah task structure, goal structure, dan reward structure. Dimana dalam Cooperative Learning terdapat beberapa metode pembelajaran yang bervariatif khususnya metode modelling the way. Menurut penelitian terdahulu yang berjudul "Implementasi Metode Modelling The Way Dalam Meningkatkan Kualitas Pembelajaran Matematika Siswa Kelas IV MI Ma'arif Surodikraman Ponorogo Tahun Pelajaran 2011/2012"Metode Modelling The Way merupakan metode pembelajaran yang mendorong siswa secara aktif menggunakan pikiran, baik untuk menemukan ide pokok dari materi, memecahkan persoalan, maupun mengaplikasikan atau mempraktekkan apa yang baru saja dipelajari dalam proses pembelajaran, setelah siswa melihat dan mendengar materi yang disampaikan oleh guru, sehingga aktifitas pembelajaran akan melibatkan aspek kognitif, afektif dan psikomotorik untuk membangun sebuah pemahaman.

Hasil penelitian tersebut selaras dengan hasil penelitian sebelumnya yang dilakukan Titik Nurwulan yang berjudul Implementasi metode modelling the way dalam meningkatkan kualitas pembelajaran matematika siswa kelas IV MI Ma'aruf Surodikraman Ponorogo tahun pelajaran 2011/2012.Dari hasil analisis siswa data yang di dapatkan bahwa (a) Aktivitas belajar matematika siswa selama pembelajaran secara keseluruhan efektif. Hal ini dapat dilihat dari aspek pengamatan yang dilakukan siswa tiap siklus aktivitas siswa yang termasuk kategori efektif lebih banyak daripada yang tidak efektif. (b) Hasil belajar siswa mengalami peningkatan dari siklus I sampai siklus II yaitu siklus I (75\%), siklus II (92\%). (c) Pengelolaan pembelajaran yang dilakukan guru berjalan dengan baik. (d) Siswa sangat tertarik terhadap pembelajaran yang telah diterapkan. Kesimpulan dari penelitian ini adalah pembelajaran aktif Modelling the way membuat siswa lebih memahami materi, lebih aktif belajar dan lebih berani mengungkapkan pendapat sehingga dapat meningkatkan kualitas pembelajaran matematika siswa keklas IV MI Ma'aruf Surodikraman Ponorogo.

Hasil penelitian terdahulu yakni (Masykuri, 2013)yang berjudul Upaya Meningkatkan Keterampilan Berbicara Melalui Model Pembelajaran Modeling The way Pada Mata Pelajaran Bahasa Indonesia Siswa 
Kelas V MIM Bekangan Boyolali Tahun Ajaran 2012/2013. Penelitian ini bertujuan untuk meningkatkan ketrampilan berbicara bahasa indonesia melalui penerapan model pembelajaran Modeling The Way. Subyek dari penelitian ini adalah guru dan siswa kelas V MIM Bekangan yang berjumlah 23 siswa yang terdiri dari 8 siswa laki - laki, dan 15 siswa perempuan, tindakan, pengamatan dan refleksi. Teknik pengumpulan data dilakukan melalui wawancaraobservasi, dokumentasi, tes. Sedangkan teknik analisis data menggunakan reduksi data, penyajian data, kesimpulan. Berdasarkan hasil penelitian menunjukkan adanya peningkatan ketrampilan berbicara Bahasa Indonesia pada materi Drama. Indikator pencapaian peningkatan yaitu sekurang-kurangnya $70 \%$ siswa memperoleh nilai $\geq \mathrm{KKm}$ yaitu $\geq 70$, sekurangkurangnya 70\% dari 23 siswa yaitu sekitar 16 anak mengalami peningkatan ketrampilan berbicara dalam Bahasa Indonesia. Peningkatan ketrampilan berbicara dalam Bahasa Indonesia dengan hasil belajar tes unjuk kerja siswa yang diperoleh data pada prasiklus sebanyak 9 siswa atau sebesar 39,13\% mengalami ketuntasan, siklus I sebanyak 16 siswa atau sebesar 69,56\% mengalami ketuntasan, pada siklus II prosentase ketuntasan yang diperoleh sebanyak 20 siswa atau sebesar 86,97\%. Kesimpulan penelitian ini adalah bahwa penerapan Modeling The Way dapat meningkatkan ketrampilan berbicara pada mata pelajaran Bahasa Indonesia Siswa kelas V MIM Bekangan tahun ajaran 2012/2013.

Berdasarkan beberapa data yang diperoleh dari hasil penelitian ini dapat diambil kesimpulan bahwa implementasi metode modelling the way dengan permainan mathchess dapat meningkatkan keterampilan perkalian siswa kelas II SD Tambakrejo 03 Semarang.

\section{Simpulan dan Saran}

Berdasarkan hasil penelitian yang dilakukan di SD Tambakrejo 03 Semarang dapat disimpulkan bahwa ketereampilan perkalian siswa kelas II meningkat pada implementasi metode modelling the way dengan permainan mathchess pada tema 2 Bermain di Lingkunganku subtema 1 Bermain di Lingkungan Rumah pembelajaran 1 . Hal ini dapat dilihat dari rata-rata data yang menunjukkan bahwa rata-rata nilai posttest lebih tinggi dibandingkan dengan rata-rata nilai pretest. Diperkuat juga dengan hasil uji hipotesis dengan menggunakan uji-t satu pihak yaitu diperoleh $t_{\text {hitung }}=10,437$. Dari daftar distribusi $t$ dengan $\mathrm{db}=\mathrm{N}$ $-1=22-1=21$ dengan taraf signifikansi $5 \%$ diperoleh ttabel $=1.721$. Karena thitung $>t_{\text {tabel }}$ maka $\mathrm{H}_{0}$ ditolak maka $\mathrm{H}_{\mathrm{a}}$ diterima sehingga dapat disimpulkan bahwa nilai posttest siswa lebih baik dibandingkan dengan nilai pretest. Hipotesis pada penelitian ini diterima. Siswa mencapai peningkatan keterampilan perkalian pada implementasi metode modelling the way dengan permainan mathchess pada siswa kelas II SD Tambakrejo 03 Semarang. Hal ini terbukti dengan rata-rata nilai posttest mencapai 93,18. Sedangkan rata-rata nilai pretest mencapai 64,77. dapat disimpulkan bahwa metode modelling the way dengan permainan mathchess berpengaruh untuk peningkatan keterampilan perkalian siswa kelas II di SD tambakrejo 03 Semarang.

Berdasarkan hasil penelitian yang dilakukan, bahwa implementasi metode modelling the way dengan permainan mathchess dapat meningkatkan keterampilan perkalian siswa kelas II SD Tambakrejo 03 Semarang sehingga saran yang bisa di paparkan yaitu: 1) Metode modelling the way dengan permainan mathchess berpengaruh untuk meningkatkan ketrampilan perkalian siswa kelas II, sehingga dapat dijadikan sebagai alternatif model dalam pembelajaran. 2) Pembelajaran dengan metode modelling the way ini dapat dikolaborasikan dengan permainan atau media yang lain sesuai dengan situasi dan kondisi di sekolah. 3) Pembelajaran dengan menggunakan metode modelling the way dengan permainan mathchess dapat menumbuhkan kerjasama serta motivasi siswa untuk semangat belajar.

\section{Daftar Rujukan}

Dacey, John S \& John F. Travers. (2002). Human development across the lifespan 5th ed. New York: The McGraw-Hill Companies, Inc.

Ardi Rakasiwi. (2018). Pengaruh Model Pembelajaran Modelling The Way Terhadap Pelaksanaan Ibadah Sehari-Hari Uin Sunan Gunung Djati Bandung, Jalan A . H . Nasution No . 105 , Cipadung , Cibiru ,

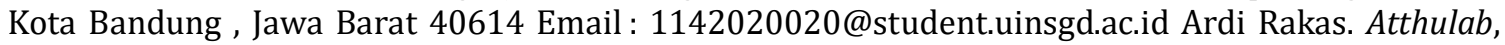
$3(1)$.

Basri. (2017). Evaluasi Profesionalisme Guru B. SULOH, 2(1), 1689-1699.

Binov handitya. (2019). Menyemai Nilai Pancasila Pada Generasi Muda Cendekia. ADIL INDONESIA JURNAL, 2(1), 47-50.

Hadi, S. (2017). Pendidikan Matematika Ralistik. Rajawali Pers.

Khasanah, U. (2011). Pengaruh Pembelajaran Make A-Match Dan Index Card Match Terhadap Pemahaman 
Siswa Kelas X Sma Institut Indonesia Semarang Tahun Ajaran 2010/2011. Jurnal Penelitian Pembelajaran Fisika, 2(2), 143-154. https://doi.org/10.26877/jp2f.v2i2/septembe.135

Masykuri, A. (2013). Upaya Meningkatkan Ketrampilan Berbicara Melaluimodel Pembelajaran Modeling the Way Pada Mata Pelajaran Bahasa Indonesia Siswa Kelas V Mim Bekangan Boyolali Tahun Ajaran 2012/2013. Pendidikan Guru Sekolah Dasar, 1-12.

Permatasari, B. I. (2014). Efektivitas Penerapan Model Pembelajaran Superitem dalam Meningkatkan Pemahaman Konsep Matematika Siswa Kelas X SMAN 11 Makassar. Jurnal Matematika Dan Pembelajaran, 2(1), 136-154. https://doi.org/10.24252/mapan.2014v2n1a10

Riris Nur Kholidah Rambe. (2018). Penerapan strategi index card match untuk meningkatkan hasil belajar siswa pada mata pelajaran bahasa indonesia. Jurnal tarbiyah, 25(1), 93-124. https://doi.org/10.30829/tar.v25i1.237

Ruslan, Fauziah, T., \& Alawiyah, T. (2016). Kendala Guru dalam Menerapkan Penilaian Autentik di SD Kabupaten Pidie. Jurnal Ilmiah Mahasiswa Pendidikan Guru Sekolah Dasar, 1(1), 147-157. https://media.neliti.com/media/publications/188254-ID-kendala-guru-dalam-menerapkanpenilaian.pdf

Sholichah, A. S. (2018). Teori-Teori Pendidikan Dalam Al-Qur'an. In Jurnal Pendidikan Islam (Vol. 07, Issue 1). https://doi.org/10.30868/EI.V7

Sihotang, I. M., \& Sari, D. M. (2018). Implementasi Model Pembelajaran Modelling The Way Dalam Meningkatkan Hasil Belajar Pada Materi. 82-87.

Wardani, E. P., Mardiyana, M., \& Subanti, S. (2016). Analisis Miskonsepsi Siswa Pada Materi Pokok Lingkaran Ditinjau Dari Kesiapan Belajar Dan Gaya Berpikir Siswa Kelas Xi Ipa Sma N 3 Surakarta Tahun Ajaran 2013/2014. Jurnal Pembelajaran Matematika, 4(3), 328-340.

Zubaidah, Magiati, \& Kresnadi, H. (2015). Peningkatan Hasil Belajar Matematika dengan Metode Lattice di Kelas III Sekolah Dasar. 2, 1-17. 